http://jmscr.igmpublication.org/home/ ISSN (e)-2347-176x ISSN (p) 2455-0450 crossref DOI: https://dx.doi.org/10.18535/jmscr/v8i4.89

\title{
A comparative study of magnesium sulphate and clonidine in attenuating hemodynamic response to pneumoperitoneum in laparoscopic cholecystectomy
}

\author{
Authors \\ Anita Pareek ${ }^{1}$, Jinesh Baid ${ }^{2 *}$, Kiwi Manthan ${ }^{3}$, Aditya Sharma ${ }^{4}$ \\ ${ }^{1}$ Sr. Professor, ${ }^{2}$ Resident, ${ }^{3}$ Assoc. Professor, ${ }^{4}$ Medical Student \\ *Corresponding Author \\ Jinesh Baid \\ Department of Anaesthesia, Sardar Patel Medical College\& AGH, Bikaner, Rajasthan, India
}

\begin{abstract}
Introduction: Laparoscopic cholecystectomy is one of the most common laparoscopic surgeries performed worldwide. Pneumoperitoneum is commonly induced by carbon dioxide $\left(\mathrm{CO}_{2}\right)$. Pneumoperitoneum affects homeostasis and leads to alterations in cardiovascular, pulmonary physiology and stress response. Pneumoperitoneum, as well as hypercapnia due to $\mathrm{CO}_{2}$, is responsible for the adverse cardiovascular effects. An abrupt elevation of mean arterial pressure, systemic vascular resistance and decreased cardiac output are commonly noted. This vasopresso responses are due to hypercarbia induced release of both catecholamines and vasopressin. Our aim was to evaluate and compare the effect of intravenously administered clonidine and magnesium sulfate for attenuating the hemodynamic responses to pneumoperitoneum during laparoscopic surgeries.

Material \& Methodology: We conducted a prospective double blinded randomized control study in 90 patients belonging to ASA I and II undergoing elective laparoscopic surgeries in S. P. medical college, Bikaner after taking approval from Institutional Ethical committee and valid written informed consent from patients and their close relatives. Patients of both sexes ranging between 18 to 60 years of age were included.

Patients were divided randomly using computer-derived random number sequence into three groups of 30 each. Group-C received clonidine $1.0 \mu \mathrm{g} / \mathrm{kg}$ in $50 \mathrm{ml}$ of normal saline. Group-M received magnesium $50 \mathrm{mg} / \mathrm{kg}$ in $50 \mathrm{ml}$ of normal saline. Group-NS received $50 \mathrm{ml}$ normal saline.

The test drug solution was given after intubation and before pneumoperitoneum. The HR, SBP, DBP, MAP were noted.

Results: In both magnesium and clonidine groups, there was no statistically significant differences observed in SBP, DBP, MAP ( $p$-value > 0.05) (statistically significant fall in HR between the group-M and group-C) but as compared to group-NS there was significant difference $(p$-value $<0.05)$ in hemodynamic parameters. In group-NS haemodyamic parameters were comparatively high as compared to other two groups.

Conclusion: Clonidine $1.0 \mu \mathrm{g} / \mathrm{kg}$ was equally effective as magnesium shulphate $50 \mathrm{mg} / \mathrm{kg}$ in blunting the hemodynamic stress response during laparoscopic surgeries as compared to normal saline group where haemodyamic parameters were comparatively high.

Keywords: Magnesium shulphate, Clonidine, Laparoscopic cholecystectomy.
\end{abstract}




\section{Introduction}

Laparoscopic cholecystectomy is one of the most common laparoscopic surgeries performed worldwide $^{1}$. Advent of laparoscopic approach to cholecystectomy revolutionized the treatment of biliary tract disease. In 1985, Prof Dr Erich Muhe of Germeny performed the first laparoscopic cholecystectomy ${ }^{2}$. Laparoscopy results in multiple postoperative benefits including less surgical trauma, less pain, less pulmonary dysfunction , quicker recovery, and shorter hospital stay ${ }^{3}$. Pneumoperitoneum is commonly induced by carbon dioxide $\left(\mathrm{CO}_{2}\right)$. Pneumoperitoneum affects homeostasis and leads to alterations in cardiovascular, pulmonary physiology and stress response $^{4}$. Pneumoperitoneum, as well as hypercapnia due to $\mathrm{CO}_{2}$, is responsible for the adverse cardiovascular effects. An abrupt elevation of mean arterial pressure, systemic vascular resistance and decreased cardiac output are commonly noted ${ }^{5}$. This vasopressor responses are due to hypercarbia induced release of both catecholamines, vasopressin or both ${ }^{6}$. The cardiac output will be further decreased by the reverse trendelenburg position used in these surgeries. A number of strategies have been used to blunt these adverse hemodynamic changes associated with pneumoperitoneum and make laparoscopic cholecystectomy safer for the high risk patients. These include using drugs like Alpha2-adrenergic agonists $^{7}$, beta-blocking agents ${ }^{8}$, opioids, vasodilators, or magnesium sulphate ${ }^{9}$ to avoid circulatory response to pneumoperitoneum, using low pressure pneumoperitoneum ${ }^{10}$, or alternatively not using pneumoperitoneum at all such as in abdominal wall lift (AWL) method. ${ }^{11}$ Our aim was to evaluate and compare the effect of intravenously administered clonidine and magnesium sulfate for attenuating the hemodynamic responses to pneumoperitoneum during laparoscopic surgeries.

\section{Material and Methodology}

We conducted a prospective double blinded randomized control study in 90 patients belonging to ASA I and II undergoing elective laparoscopic surgeries in S. P. medical college, Bikaner after taking approval from Institutional Ethical committee and valid written informed consent from patients and their close relatives. Patients of both sexes ranging between 18 to 60 years of age were included. Age below 18 years, above 60 year, patients with hypermagnesemia, known allergy to magnesium sulfate or clonidine, hypertension, morbid obesity, severe hepatic, renal, endocrine, and cardiac dysfunction and patients in whom laparoscopic cholecystectomy converted to open cholecystectomy were excluded from study.

Patients were divided randomly using computerderived random number sequence into three groups of 30 each. Group-C received inj. clonidine $1.0 \mu \mathrm{g} / \mathrm{kg}$ in $50 \mathrm{ml}$ of normal saline over $10 \mathrm{~min}$, prior to pneumoperitoneum. Group-M received inj. Magnesium shulphate $50 \mathrm{mg} / \mathrm{kg}$ in 50 $\mathrm{ml}$ of normal saline over $10 \mathrm{~min}$, prior to pneumoperitoneum. Group-NS received $50 \mathrm{ml}$ normal saline over $10 \mathrm{~min}$, prior to pneumoperitoneum.

On the day prior to surgery a thorough clinical examination of the patient were done including general physical examination and systemic examination. Routine investigations like CBC,BT, $\mathrm{CT}$, urine analysis, fasting blood sugar, Liver function test, chest x-ray, Blood urea, serum creatinine, ECG, Viral markers were done. All patients were explained about the anaesthesia technique and written informed consent was taken from patients and their relatives. Patient was kept NBM for 8-10 hours.

Premedication with inj ranitidine $50 \mathrm{mg}$ and inj ondansetron $4 \mathrm{mg}$ was given 2 hours before surgery in preoperative room. On arrival in the operation theatre pulse oximeter, NIBP, ECG were connected to the patients and baseline vital parameters were recorded. Preoxygenation was done for $3 \mathrm{~min}$ and patients received $0.005 \mathrm{mg} / \mathrm{kg}$ of inj glycopyrrolate and $2 \mu \mathrm{g} / \mathrm{kg}$ of fentanyl citrate intravenously. Propofol $2 \mathrm{mg} / \mathrm{kg}$ was used for induction and endotracheal intubation was 
facilitated by a muscle relaxant, vecuronium bromide $0.1 \mathrm{mg} / \mathrm{kg}$. The test drug was infused over $10 \mathrm{~min}$ before creating pneumoperitoneum. Systolic blood pressure (SBP), diastolic blood pressure (DBP), MAP, and HR were recorded before induction (baseline values), at the end of magnesium sulfate/clonidine/saline administration and before pneumoperitoneum (P0), $5 \mathrm{~min}$ (P5), $10 \mathrm{~min}$ (P10), $20 \mathrm{~min}$ (P20), $30 \mathrm{~min}$ (P30), and 40 min (P40) so on every $10 \mathrm{~min}$ after pneumoperitoneum. Pneumoperitoneum inflation pressures was maintained at $14 \mathrm{~mm} \mathrm{Hg}$. Maintenance of anesthesia was with nitrous oxide $(50 \%)$, oxygen $(50 \%)$, and isoflurane and titrated doses of vecuronium $0.02 \mathrm{mg} / \mathrm{kg}$. Intermittent positive pressure ventilation was used and endtidal $\mathrm{CO}_{2}\left(\mathrm{EtCO}_{2}\right)$ was maintained between 35 and $40 \mathrm{~mm} \mathrm{Hg}$. Patients were positioned in head up tilt of $15^{\circ}$ with right lateral tilt. During surgery, I.V. fluid ringer lactate was infused in accordance with maintenance volume requirements and blood loss. Hypotension (MAP $<20 \%$ of baseline) was managed with fluid bolus or mephentermine $6 \mathrm{mg}$ IV. Atropine $0.6 \mathrm{mg}$ IV was given if $\mathrm{HR}<$ 50/min. Neuromuscular blockade was reversed with i.v. inj. neostigmine $0.05 \mathrm{mg} / \mathrm{kg}$ and glycopyrrolate $0.01 \mathrm{mg} / \mathrm{kg}$ and extubation was done.

\section{Data Analysis}

A pre-structured pre-tested proforma was used for Data collection and for data analysis Microsoft excel was used. The sample size was calculated according to significant difference between drug group and placebo group and it was estimated that a sample size of 28 patients for each group would be sufficient to detect a difference of $15 \mathrm{~mm} \mathrm{hg}$ between drug group and placebo group with a significant level of $<0.05$ and power of study as $80 \%$. Continuous variable were expressed as mean (SD) and compared with student's t-test. Difference between proportion derived from categorical data were compared with chi square test. For all the p-values of less than 0.05 was considered significant.

\section{Results}

Table 1-4 shows the demographic variables of the patients in the three groups. All three groups were comparable in respect to age, body weight, sex, ASA status. The baseline vitals were comparable between all the groups.

In table-5 fall in SBP was statistically insignificant in group-M and group-C ( $\mathrm{p}$ value > $0.05)$. Statistically significant fall in SBP from $\mathrm{P} 5$ till extubation noted in group-M \& group-NS ( $p$ value $<0.05$ ) and group-C \& group-NS ( $\mathrm{p}$ value $<0.05)$.

Table- 6 shows statistically insignificant fall in DBP in group-M and group-C ( $\mathrm{p}$ value > 0.05). Significant fall in DBP from P5 till extubation noted in group-M \& group-NS (p value <0.05) and in group-C \& group-NS ( $\mathrm{p}$ value $<0.05$ ).

Table-7 shows statistically insignificant fall in MAP noted between group-M \& group-C ( $\mathrm{p}$ value $>0.05$ ). Significant fall in MAP from P5 to P40 and at the time of extubation in group-M \& groupNS and in group-C \& group-NS (p value <0.05).

Table 8 shows statistically significant fall in heart rate between the group-M and group- $\mathrm{C}$, group-M and group-NS, and group-C and group-NS (p value $<0.05$ ).

No significant episodes of hypotension or bradycardia were noted in any group.

Table: 1 Age wise distribution of study groups.

\begin{tabular}{|l|c|c|c|c|}
\hline Age Group & Group-M & Group-C & Group-NS & P-value \\
\hline 21-30 years & $9(30 \%)$ & $16(53.3 \%)$ & $10(33.3 \%)$ & \\
\cline { 1 - 4 } $31-40$ years & $12(40 \%)$ & $6(20 \%)$ & $6(20 \%)$ & \\
\cline { 1 - 4 } 41-50 years & $6(20 \%)$ & $4(13.3 \%)$ & $6(20 \%)$ & \\
\cline { 1 - 4 } $51-60$ years & $3(10 \%)$ & $4(13.4 \%)$ & $8(26.7 \%)$ & \multirow{2}{*}{0.3267} \\
\hline Mean+SD & $37 \pm 11.7$ & $34.1 \pm 11.0$ & $38.9 \pm 12.2$ & \\
\hline
\end{tabular}

Table: 2 Comparison of groups on basis of Mean body weight.

\begin{tabular}{|l|c|c|}
\hline Weight $(\mathrm{kg})$ & Mean \pm SD & P-value \\
\hline Group-M & $60.7 \pm 5.6$ & \multirow{2}{*}{0.8910} \\
\hline Group-C & $60.1 \pm 9.1$ & \\
\hline Group-NS & $63.2 \pm 8.3$ & \\
\hline
\end{tabular}

Table: 3 Gender wise distribution of patients.

\begin{tabular}{|l|c|c|c|}
\hline Gender & Group-M & Group-C & Group-NS \\
\hline Female & $26(86.7 \%)$ & $25(83.3 \%)$ & $22(73.3 \%)$ \\
\hline Male & $4(13.3 \%)$ & $5(16.7 \%)$ & $8(26.7 \%)$ \\
\hline
\end{tabular}


Table: 4 Comparison of groups on the basis of ASA Status.

\begin{tabular}{|l|c|c|c|}
\hline ASA Grade & ASA 1 & ASA 2 & P-value \\
\hline Group-M & $27(90 \%)$ & $3(10 \%)$ & \multirow{2}{*}{} \\
\cline { 1 - 3 } Group-C & $28(93.3 \%)$ & $2(6.7 \%)$ & \multirow{2}{*}{0.7841} \\
\hline Group-NS & $30(100 \%)$ & $0(0 \%)$ & \multirow{2}{*}{} \\
\hline
\end{tabular}

Table: 5 Comparison of groups on basis of Mean systolic blood pressure.

\begin{tabular}{|c|c|c|c|c|c|c|}
\hline \multirow[t]{2}{*}{ SBP (mmhg) } & GROUP-M & GROUP-C & GROUP- & \multicolumn{3}{|c|}{$\mathrm{P}$-value } \\
\hline & \multicolumn{3}{|c|}{ Mean \pm SD } & Group M & Group M & Group C \\
\hline Baseline & $127.3 \pm 8.5$ & $126.6 \pm 7.7$ & $127.1 \pm 12.5$ & 0.7394 & 0.6891 & 0.6514 \\
\hline After administration & $124.3 \pm 9.6$ & $123.3 \pm 8.1$ & $125.3 \pm 12.9$ & 0.6471 & 0.6521 & 0.7812 \\
\hline Before pneumoperitoneum & $118 \pm 11.2$ & $119.1 \pm 11.1$ & $121.1 \pm 11.9$ & 0.5147 & 0.3031 & 0.6214 \\
\hline $5 \min$ & $122.6 \pm 11.8$ & $122.1 \pm 13.4$ & $134.6 \pm 11.1$ & 0.8971 & 0.0002 & 0.0002 \\
\hline $10 \mathrm{~min}$ & $126.4 \pm 12.1$ & $123.1 \pm 15.9$ & $138.5 \pm 11.5$ & 0.3694 & 0.0012 & 0.0001 \\
\hline $20 \mathrm{~min}$ & $122.9 \pm 12.2$ & $117.5 \pm 17.4$ & $136.9 \pm 12.7$ & 0.1693 & 0.0031 & 0.0001 \\
\hline $30 \mathrm{~min}$ & $115.5 \pm 12$ & $115.7 \pm 16.7$ & $134.8 \pm 13.8$ & 0.8125 & 0.0003 & 0.031 \\
\hline $40 \min$ & $115.1 \pm 12.9$ & $116.1 \pm 16.6$ & $124.4 \pm 14.3$ & 0.7815 & 0.0061 & 0.0424 \\
\hline Extubation & $127.5 \pm 10.6$ & $132.8 \pm 13.0$ & $146.5 \pm 11.7$ & 0.0888 & 0.0001 & 0.0001 \\
\hline
\end{tabular}

Table: 6 Comparison of groups on basis of Mean diastolic blood pressure.

\begin{tabular}{|l|c|c|c|c|c|c|}
\hline \multirow{2}{*}{ DBP (mmhg) } & GROUP-M & GROUP-C & GROUP-NS & \multicolumn{3}{c|}{ P-value } \\
\cline { 2 - 7 } & \multicolumn{3}{|c|}{ Mean \pm SD } & $\begin{array}{c}\text { Group M } \\
\text { and C }\end{array}$ & $\begin{array}{c}\text { Group M } \\
\text { and NS }\end{array}$ & $\begin{array}{c}\text { Group C } \\
\text { and NS }\end{array}$ \\
\hline Baseline & $83.3 \pm 6.7$ & $82.0 \pm 6.3$ & $81.1 \pm 9.4$ & 0.8214 & 0.702 & 0.0687 \\
\hline After administration & $81.1 \pm 6.8$ & $80.7 \pm 7.8$ & $80.2 \pm 7.6$ & 0.7394 & 0.6891 & 0.5147 \\
\hline Before pneumoperitoneum & $76.7 \pm 9.0$ & $79.7 \pm 8.8$ & $75.7 \pm 9.0$ & 0.6471 & 0.6521 & 0.1201 \\
\hline $5 \mathrm{~min}$ & $80.9 \pm 8.3$ & $83.3 \pm 6.8$ & $90.2 \pm 9.1$ & 0.05211 & 0.0001 & 0.0015 \\
\hline $10 \mathrm{~min}$ & $85.1 \pm 7.8$ & $83.0 \pm 9.7$ & $89.9 \pm 9.2$ & 0.5147 & 0.04 & 0.017 \\
\hline $20 \mathrm{~min}$ & $81.4 \pm 8.6$ & $77.6 \pm 11.0$ & $85.2 \pm 7.8$ & 0.1415 & 0.051 & 0.0095 \\
\hline $30 \mathrm{~min}$ & $73.9 \pm 9.1$ & $77.4 \pm 9.3$ & $83.6 \pm 8.4$ & 0.1461 & 0.0001 & 0.0001 \\
\hline $40 \mathrm{~min}$ & $71 \pm 9.5$ & $72.1 \pm 12.3$ & $79.5 \pm 4.6$ & 0.214 & 0.0038 & 0.0035 \\
\hline Extubation & $85.5 \pm 10.9$ & $85.2 \pm 7.7$ & $92.4 \pm 7.7$ & 0.8125 & 0.0064 & 0.0071 \\
\hline
\end{tabular}

Table: 7 Comparison of groups on basis of Mean arterial pressure.

\begin{tabular}{|l|c|c|c|c|c|c|}
\hline \multirow{2}{*}{ MAP (mmhg) } & GROUP-M & GROUP-C & GROUP-NS & \multicolumn{3}{c|}{ P-value } \\
\cline { 2 - 7 } & \multicolumn{3}{|c|}{ Mean \pm SD } & $\begin{array}{c}\text { Group M } \\
\text { and C }\end{array}$ & $\begin{array}{c}\text { Group M } \\
\text { and NS }\end{array}$ & $\begin{array}{c}\text { Group C } \\
\text { and NS }\end{array}$ \\
\hline Baseline & $96.4 \pm 6.7$ & $96.8 \pm 5.7$ & $96.1 \pm 7.3$ & 0.8214 & 0.701 & 0.5147 \\
\hline After administration & $93.0 \pm 7.3$ & $94.7 \pm 7.5$ & $96.2 \pm 9.6$ & 0.5147 & 0.087 & 0.0687 \\
\hline Before pneumoperitoneum & $89.7 \pm 8.7$ & $92.3 \pm 8.4$ & $91.3 \pm 10.5$ & 0.1461 & 0.0614 & 0.7511 \\
\hline $5 \mathrm{~min}$ & $94.4 \pm 8.3$ & $95.9 \pm 8.0$ & $102.5 \pm 8.6$ & 0.8125 & 0.0021 & 0.0095 \\
\hline $10 \mathrm{~min}$ & $98.5 \pm 9.6$ & $95.3 \pm 10.8$ & $104.5 \pm 10.4$ & 0.6891 & 0.0071 & 0.0038 \\
\hline $20 \mathrm{~min}$ & $95.5 \pm 8.7$ & $89.9 \pm 12.2$ & $101.9 \pm 8.9$ & 0.0818 & 0.0311 & 0.0001 \\
\hline $30 \mathrm{~min}$ & $88.3 \pm 8.2$ & $89.5 \pm 12.1$ & $102.1 \pm 9.7$ & 0.6817 & 0.0001 & 0.0001 \\
\hline $40 \mathrm{~min}$ & $85.7 \pm 9.8$ & $86.8 \pm 13.7$ & $91.0 \pm 13.0$ & 0.0871 & 0.014 & 0.017 \\
\hline Extubation & $98.9 \pm 10.7$ & $99.9 \pm 9.3$ & $110.9 \pm 9.3$ & 0.5061 & 0.0001 & 0.0006 \\
\hline
\end{tabular}

Table: 8 Comparison of groups on basis of Heart Rate.

\begin{tabular}{|l|c|c|c|c|c|c|}
\hline \multirow{2}{*}{ HR (beats/min) } & GROUP-M & GROUP-C & GROUP-NS & \multicolumn{3}{c|}{ P-value } \\
\cline { 2 - 7 } & \multicolumn{3}{|c|}{ Mean \pm SD } & $\begin{array}{c}\text { Group M } \\
\text { and C }\end{array}$ & $\begin{array}{c}\text { Group M and } \\
\text { NS }\end{array}$ & $\begin{array}{c}\text { Group C and } \\
\text { NS }\end{array}$ \\
\hline Baseline & $90.1 \pm 11.3$ & $95 \pm 13.9$ & $90.1 \pm 8.4$ & 0.5147 & 0.701 & 0.6151 \\
\hline After administration & $81.9 \pm 7.7$ & $92.5 \pm 13.5$ & $98.1 \pm 7.1$ & 0.0038 & 0.7511 & 0.0490 \\
\hline Before pneumoperitoneum & $81.3 \pm 5.3$ & $89.9 \pm 17.0$ & $103.3 \pm 4.9$ & 0.0001 & 0.1534 & 0.0001 \\
\hline $5 \mathrm{~min}$ & $82.1 \pm 7.4$ & $93.1 \pm 12.3$ & $104.1 \pm 5.1$ & 0.0001 & 0.0001 & 0.0001 \\
\hline $10 \mathrm{~min}$ & $84.1 \pm 8.1$ & $93.8 \pm 10.5$ & $104.7 \pm 5.6$ & 0.0001 & 0.0001 & 0.0001 \\
\hline $20 \mathrm{~min}$ & $84.3 \pm 6.3$ & $91.4 \pm 8.5$ & $103.4 \pm 4.1$ & 0.0001 & 0.0001 & 0.0001 \\
\hline $30 \mathrm{~min}$ & $82.4 \pm 6.2$ & $93.0 \pm 8.1$ & $100.7 \pm 4.6$ & 0.0006 & 0.0001 & 0.0001 \\
\hline $40 \mathrm{~min}$ & $84.1 \pm 6.9$ & $79.7 \pm 6.2$ & $98.9 \pm 1.7$ & 0.0071 & 0.0001 & 0.0001 \\
\hline Extubation & $94.9 \pm 7.8$ & $98.9 \pm 12.3$ & $101.2 \pm 5.9$ & 0.0091 & 0.0021 & 0.041 \\
\hline
\end{tabular}




\section{Discussion}

Laparoscopic surgeries are being performed more and more frequently now a days for various elective procedures. . So there is a need for the better control of hemodynamics intraoperatively in these types of surgeries. Various pharmacological agents have been studied in the recent past for attenuating the hemodynamic responses to the laparoscopy. Most of the studies have compared the effect of intravenous clonidine or magnesium with that of the control. Very few studies are available that compare intravenous clonidine with magnesium for attenuation of the hemodynamic responses to laparoscopy. We did a prospective, randomized, double blinded study to compare the effect of intravenous clonidine and magnesium on hemodynamic response to pneumoperitoneum in patients undergoing laparoscopic surgeries.

Kalra et $\mathrm{al}^{7}$ compared the attenuation of hemodynamic response during laparoscopic cholecystectomy due to pneumoperitoneum was infused with intravenous clonidine $1 \mu \mathrm{g} / \mathrm{kg}$, clonidine $1.5 \mu \mathrm{g} / \mathrm{kg}$, magnesium $50 \mathrm{mg} / \mathrm{kg}$ and placebo and found that both clonidine doses and magnesium had significant attenuation on hemodynamic stress response when compared with placebo. The test drugs solution were infused after intubation for 15 minutes. Clonidine $1.5 \mu \mathrm{g} / \mathrm{kg}$ showed statistically significant difference with magnesium $50 \mathrm{mg} / \mathrm{kg}$ with no incidence of adverse events like bradycardia and hypotension.

Altan et $\mathrm{al}^{12}$ used clonidine $3 \mu \mathrm{g} / \mathrm{kg}$ intravenously over a period of 15 minutes before induction and then $2 \mu \mathrm{g} / \mathrm{kg} / \mathrm{min}$ by continuous infusion intraoperatively. They observed significant incidences of bradycardia and hypotension in their study. Ray et $\mathrm{al}^{13}$ used $3 \mu \mathrm{g} / \mathrm{kg}$ of clonidine intravenously over a period of $15 \mathrm{~min}$ before induction and then $1 \mu \mathrm{g} / \mathrm{kg} / \mathrm{min}$ by continuous infusion during surgery and observed significant incidences of bradycardia and hypotension in their study. We used clonidine $1 \mu \mathrm{g} / \mathrm{kg}$, given before pneumoperitoneum and we did not observe any complications similar to study conducted by Kalra et $\mathrm{al}^{7}$.

Jee et $\mathrm{al}^{9}$ administered magnesium sulfate 50 $\mathrm{mg} / \mathrm{kg}$ over 2-3 minutes, before pneumoperitoneum in patients undergoing laparoscopic cholecystectomy and observed that it effectively attenuated the hemodynamic stress response due to pneumoperitoneum without any episode of severe hypotension or bradycardia.

Kalra et $\mathrm{al}^{7}$ observed that statistically significant decrease in heart rate in patients who received clonidine $1.5 \mu \mathrm{g} / \mathrm{kg}$ at the following intervals; 30 minutes after pneumoperitoneum $(\mathrm{P}<0.05)$ and 40 minutes after pneumoperitoneum $(\mathrm{P}<0.05)$ than magnesium $50 \mathrm{mg} / \mathrm{kg}$ group. There was no statistically significant difference in heart rate between the clonidine $1 \mu \mathrm{g} / \mathrm{kg}$ and magnesium $50 \mathrm{mg} / \mathrm{kg}$. This did not coincide with our study.

Altan et $\mathrm{al}^{12}$ observed that there was no statistically significant difference in systolic blood pressure observed between the patients who received clonidine $3 \mu \mathrm{g} / \mathrm{kg}$ bolus followed by $2 \mu \mathrm{g} / \mathrm{kg} / \mathrm{hr}$ infusion and magnesium sulphate $30 \mathrm{mg} / \mathrm{kg}$ as a bolus followed by $10 \mathrm{mg} / \mathrm{kg} / \mathrm{hr}$ infusion. Jee et $\mathrm{al}^{9}$ conducted a study in which patients received magnesium sulphate $50 \mathrm{mg} / \mathrm{kg}$, infused immediately before pneumoperitoneum, showed statistically significant decrease in systolic blood pressure at 10 minutes $(\mathrm{P}<0.05)$, 20 minutes $(\mathrm{P}<0.05)$ and 30 minutes after pneumoperitoneum $(\mathrm{P}<0.05)$ than the placebo group. The observation of our study goes in concordance with above studies like Altan et $\mathrm{al}^{12}$ and Jee et $\mathrm{al}^{9}$.

Altan et $\mathrm{al}^{12}$ observed that there was no statistically significant difference in diastolic blood pressure observed between the patients who received clonidine $3 \mu \mathrm{g} / \mathrm{kg}$ bolus followed by $2 \mu \mathrm{g} / \mathrm{kg} / \mathrm{hr}$ infusion, and magnesium sulphate $30 \mathrm{mg} / \mathrm{kg}$ as a bolus followed by $10 \mathrm{mg} / \mathrm{kg} / \mathrm{hr}$ infusion. Jee et $\mathrm{al}^{9}$ conducted a study in which patients received magnesium sulphate $50 \mathrm{mg} / \mathrm{kg}$, infused immediately before pneumoperitoneum, showed statistically significant decrease in diastolic blood pressure at 10 minutes $(\mathrm{P}<0.05)$, 
20 minutes $(\mathrm{P}<0.05)$ and 30 minutes after pneumoperitoneum $(\mathrm{P}<0.05)$ than the placebo group. The above studies were in favour our study.

In our study, there was no statistically significant fall in diastolic blood pressure is noted between the group-M and group-C. There was significant fall in diastolic blood pressure from P5 till extubation in group-M and group-NS. Similarly, in group-C and group-NS significant fall in diastolic blood pressure was also found from P5 till extubation.

Mishra et $\mathrm{al}^{14}$ observed that the patient who received clonidine $1.5 \mu \mathrm{g} / \mathrm{kg}$ showed a statistically significant difference in mean arterial pressure at the following intervals; 5 minutes after pneumoperitoneum (P- 0.037) , 10 minutes after pneumoperitoneum $(\mathrm{P}<0.001), 15$ minutes after pneumoperitoneum (P- 0.006) and 20 minutes, 25 minutes, 30 minutes, 35 minutes and 40 minutes pneumoperitoneum $(\mathrm{P}<0.01)$.

\section{Conclusion}

Intravenous administration of clonidine $1.0 \mu \mathrm{g} / \mathrm{kg}$ before pneumoperitoneum is as effective as intravenous magnesium sulfate $50 \mathrm{mg} / \mathrm{kg}$ before pneumoperitoneum in blunting the haemodynamic stress responses during laparoscopic surgeries.

\section{Reference}

1. Matovic E, Hasukic S, Ljuca F, Halilovic H. Quality of life in patients after laparoscopic and open cholecystectomy. Med Arh. 2012;66(2):97-100.

2. Walker Reynolds. The First Laparoscopic Cholecystectomy. JSLS.2001 JanMarch;5(1);89-94

3. Schirmer BD, Edge SB, Dix J, Hyser MJ, Hanks JB, Jones RS. Laparoscopic cholecystectomy. Treatment of choice for symptomatic cholelithiasis. Ann Surg. 1991 Jun;213(6):665-76; discussion 677.

4. McLaughlin JG, Scheeres DE, Dean RJ, Bonnell BW. The adverse hemodynamic effects of laparoscopic cholecystectomy. Surg Endosc. 1995 Feb;9(2):121-4.

5. Joris JL, Chiche JD, Canivet JL, Jacquet NJ, Legros JJ, Lamy ML. Hemodynamic changes induced by laparoscopy and their endocrine correlates: Effects of clonidine. J Am Coll Cardiol. 1998;32:1389-96.

6. Mikami O, Kawakita S, Fujise K, Shingu K, Takahashi H, Matsuda T. Catecholamine release caused by carbon dioxide insufflation during laparoscopic surgery. J Urol. 1996;155:1368-71.

7. Kalra NK, Verma A, Agarwal A, Pandey H. Comparative study of intravenously administered clonidine and magnesium sulfate on hemodynamic responses during laparoscopic cholecystectomy. J Anaesthesiol Clin Pharmacol. 2011;27:344-8.

8. Koivusalo AM, Scheinin M, Tikkanen I, Yli-Suomu T, Ristkari S, Laakso J. Effects of esmolol on haemodynamic response to $\mathrm{CO} 2$ pneumoperitoneum for laparoscopic surgery. Acta Anaesthesiol Scand. 1998;42:510-7.

9. Jee D, Lee D, Yun S, Lee C. Magnesium sulphate attenuates arterial pressure increase during laparoscopic cholecystectomy. Br J Anaesth. 2009;103:484-9.

10. Sarli L, Costi R, Sansebastiano G, Trivelli $\mathrm{M}$, Roncoroni L. Prospective randomized trial of low-pressure pneumoperitoneum for reduction of shoulder-tip pain following laparoscopy. Br J Surg. 2000 Sep;87(9):1161-5

11. Lindgren L, Koivusalo AM, Kellokumpu I. Conventional pneumoperitoneum compared with abdominal wall lift for laparoscopic cholecystectomy. $\mathrm{Br} \quad \mathrm{J}$ Anaesth. 1995 Nov;75(5):567-72

12. Altan A, Turgut N, Yildiz F, Türkmen A, Ustün $\mathrm{H}$. Effects of magnesium sulphate and clonidine on propofol consumption, haemodynamics and postoperative recovery. Br J Anaesth. 2005 Apr;94(4): 438-41. Epub 2005 Jan 14. 
13. Ray M, Bhattacharjee DP, Hajra B, Pal R, Chatterjee N. Effect of clonidine and magnesium sulphate on anaesthetic consumption, haemodynamics and postoperative recovery: A comparative study. Indian J Anaesth. 2010 Mar; 54(2): 137-41.

14. Mishra M, Mishra SP, Mathur SK. Clonidine versus nitroglycerin infusion in laparoscopic cholecystectomy. JSLS. 2014 Jul-Sep;18(3). pii: e2014.00305. 